America. A document called The Report of the Investigating Commission, issued by the imperial military authorities and dealing with the investigation following the Decembrist revolt of 1825 , is considered extremely rare even in the Soviet Union.

Censorship of printed materials began at the end of the 18 th century with the appearance of private printing presses under Catherine II. Earlier, official supervision was considered unnecessary because the government had assumed the role of publisher and owned all the presses.

Early banned books included the 1789 Russian translation of Thomas More's Utopia, which was destroyed; Radishchev's Journey from St. Petersburg to Moscow, which was burned in 1790; and Voltaire's books, which were confiscated. In the 19 th and early 20 th century, "cases of confiscation and destruction of books became so common that simply to list the thousands of titles that were victims of censorship would require a special publica- tion," Durman said. After the 1917 October Revolution, a period of total regulation began that has not ceased.

Among the exhibit's censored books is a copy of Mikhail Shcherbatov's On the Corruption of Morals in Russia, published in 1876. Prince Shcherbatov was one of the first Russians to criticize Peter the Great for introducing corrupt Western mores into traditional Russian family values. "His pamphlet gives a lurid account of the misconduct of 18th-century Russian empresses and their favorites," Durman said.

Choldin said that microfilm copies would be made of any rare book of which the substance is not otherwise available. With some 500,000 volumes, the Illinois Slavic collection ranks third in the United States, behind those at the Library of Congress and Harvard. While more than half are written in the languages of the Soviet Union, the library holds strong Czech, Yugoslavian, Bulgarian, Polish, Romanian and Hungarian collections.

\title{
ACRL chapters
}

\section{Meet ACRL's local representatives.}

\begin{abstract}
A demic and research librarians and the ACRL Headquarters. Thirty-five regional and state ACRL chapters now cover thirty-nine states and one Canadian province, and provide opportunities for local participation for nearly $8,000 \mathrm{ACRL}$ members who live within those areas. To find out how you can participate, contact the chair of the chapter nearest to you.

If you would like to start a chapter in your region, contact Judith Kharbas, Chair of the Chapters Council New ACRL State Chapters Committee, Rhees Library, University of Rochester, Rochester, NY 14627.
\end{abstract}

Arizona Chapter (est. 1982)

Rosanna Miller, Map Collection, Arizona State
University Library, Tempe, AZ 85287.

California Chapter (est. 1979)

Elizabeth M. Salzer, Librarian, Michel Orradre Library, University of Santa Clara, CA 95053.

Colorado Chapter (est. 1983)

Christina Woo, 1933 E. 23d Ave., Denver, CO 80303.

Delaware Valley Chapter (est. 1969)

Judith M. Feller, Documents Librarian, Kemp Library, East Stroudsburg University, East Stroudsburg, PA 18301.

Florida Chapter (est. 1978)

Althea Jenkins, Director, Sarasota Campus Library, University of South Florida, 5700 N. Ta- 


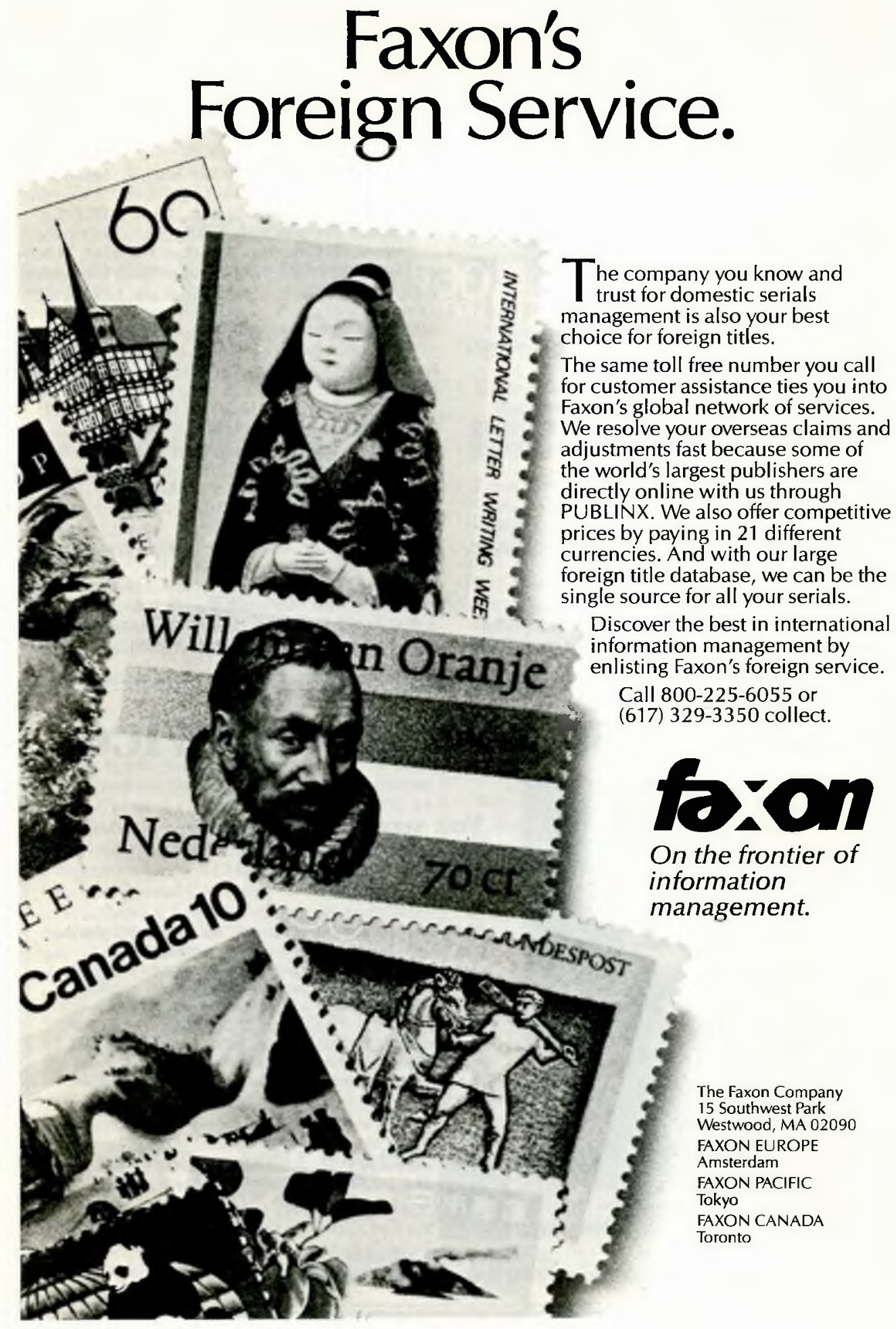


miami Trail, Sarasota, FL 33580.

Georgia Chapter (est. 1980)

Janice C. Fennell, 180 Admiralty Way, NW, Milledgeville, GA 31061.

Illinois Chapter (est. 1973)

Donna Goehner, 600 Meadow Dr., Macomb, IL 61455 .

Indiana Chapter (est. 1980)

Bernice Hollenhorst, Director, Alumnae Centennial Library, St. Mary's College, State Highway, Notre Dame, IN 46556.

\section{Iowa Chapter (est. 1976)}

Elizabeth Kaschins, Luther College Library, Decorah, IA 52101.

\section{Kansas Chapter (est. 1975)}

Diane Slater, Coordinator, Library Instructional Services, Farrell Library, Kansas State University, Manhattan, KS 66506.

\section{Louisiana Chapter (est. 1982)}

Phoebe Timberlake, Serials Librarian, Long Library, University of New Orleans, New Orleans, LA 70148 .

\section{Maryland Chapter (est. 1977)}

Simmona Simmons, Associate Reference Librarian, Kuhn Library, University of Maryland, Balti- more County, 5401 Willans Ave., Baltimore, MD 21228

Michigan Chapter (est. 1974)

Louise Bugg, Wayne State University Library, Detroit, MI 48202.

Minnesota Chapter (est. 1975)

Carol A. Johnson, 3429 32d Ave., S., Minneapolis, MN 55406 .

Mississippi Chapter (est. 1981)

Frances N. Coleman, Associate Director, Mitchell Memorial Library, Mississippi State University, P.O. Drawer 5408, Mississippi State, MS 39762.

Missouri Chapter (est. 1952)

Nancy Hanks, Director of Libraries, Wells Library, Northwest Missouri State, Marysville, MO 64468

Montana Chapter (est. 1985)

Barbara DeFelice, Reference Librarian, Reene Library, Montana State University, Bozeman, MT 59717.

Nebraska Chapter (est. 1980)

Tom Cashore, University of Nebraska Library, Lincoln, NE 68588.

Nevada Chapter (est. 1985)

Sue Kendall, Special Projects Librarian, University of Nevada, Las Vegas, NV 89154.

\section{Midwest Library Service}

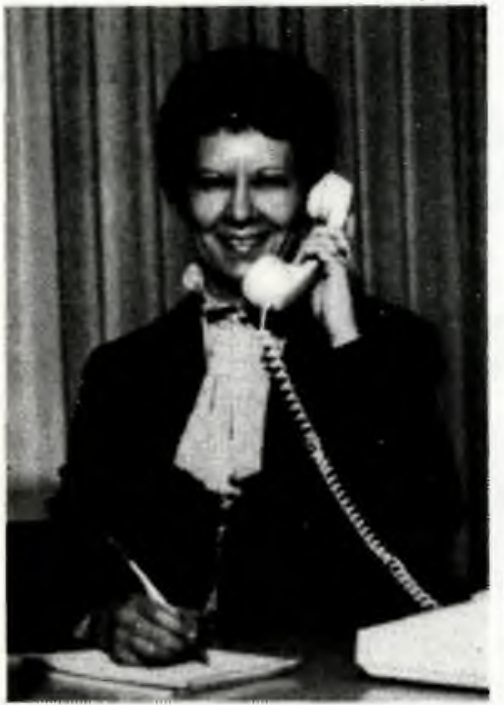

\section{You won't find more personal attention ... anywhere}

College and university librarians: We have what you're looking for. While Midwest utilizes state-of-the-art computer systems, we realize machines can't do it all. So when you want to place an order, ask a question, or discuss a problem, you can call direct on Midwest's toll-free WATS line and conduct business on a nameto-name basis with your personal customer service representative. It's the kind of attention that Midwest has provided to college and university libraries for 24 years.

Call toll-free (800) 325-8833

Missouri librarians call toll-free (800) 392-5024 Canadian librarians call collect (314) $739-3100$ 
New England Chapter (est. 1972)

Artemis Kirk, Director of Libraries, Simmons College, 300 The Fenway, Boston, MA 02115.

New Jersey Chapter (est. 1979)

Norma Yueh, Director, Ramapo College Library, 505 Ramapo Valley Rd., Mahwah, NJ 07430 .

New York Chapter, Eastern (est. 1975)

Christine Root, Associate Professor, Hudson Valley Community College, Troy, NY 12180.

New York Chapter, Greater Metropolitan Area (est. 1980)

Ann N. Meronet, Head, Periodicals Dept., Hunter College Library, 695 Park Avenue, New York, NY 10021.

New York (Western)/Ontario Chapter (est. 1975)

Deborah B. Smith, Director of Public Services, Keating Library, Roberts Wesleyan College, 2301 West Side Drive, Rochester, NY 14624.

North Carolina Chapter (est. 1978)

Robert N. Bland, Technical Services Librarian, Ramsey Library, University of North Carolina, Asheville, NC 28804.

\section{North Dakota Chapter (est. 1984)}

Jon A. Boone, Coordinator of Collection Development, Fritz Library, University of North Dakota, Grand Forks, ND 58202.

\section{0 years of Texas independence}

Rare books, manuscripts, letters, maps, and prints from the Special Collections Department of the University of Houston Libraries will be highlighted in a year-long Texas Sesquicentennial project developed jointly by the staff of the University's Office of Media Relations and the Library's Special Collections.

To celebrate Texas' independence from Mexico in 1836, a special 52-week column, "Journey Through Texas," is being offered to select newspapers across the state. Each article, written as if the author were a part of the scene described, will feature an item from the Library's Special Collections. As of mid-August, 35 newspapers statewide have subscribed to the series, which is offered free of charge.

Concurrent with each week's newspaper coverage, KTRH Radio in Houston has agreed to run several 60-second weekend spots using the articles written by the University of Houston's Office of Media Relations Staff. These will be read by Ray Miller, a pioneer broadcast journalist whose television program, "The Eyes of Texas," is the oldest and best known travel and historical series to be aired on Texas television.
Ohio Chapter (est. 1981)

Paula N. Warnken, Director, McDonald Memorial Library, Xavier University, 3800 Victory Parkway, Cincinnati, OH 45207.

\section{Oklahoma Chapter (est. 1981)}

Robert H. Patterson, Director of Libraries, McFarlin Library, University of Tulsa, 600 S. College Ave., Tulsa, OK 74104

\section{Oregon Chapter (est. 1975)}

Rebecca Thompson, Acting Director, LRC, Central Oregon Community College, NW College Way, Bend, OR 97701.

\section{South Dakota Chapter (est. 1981)}

Leon Raney, Dean of Libraries, South Dakota State University, Box 2115, Brookings, SD 57007.

Tennessee Chapter (est. 1976)

Margaret Anderson, Head of Acquisitions, Todd Library, Middle Tennessee State University, Box 13, Murfreesboro, TN 37130.

\section{Texas Chapter (est. 1977)}

Maxine Johnston, Director, Gray Library, Lamar University, Box 10021, Lamar Station, Beaumont, TX 77710.

Virginia Chapter (est. 1977)

Catherine V. Bland, Director of Library Services, Johnson Memorial Library, Box JJ, Virginia State University, Petersburg, VÄ 23803.

\section{Washington State Chapter (est. 1980)}

John P. Backes, Reference Services, Howard Library/Media Center, Shoreline Community College, 16101 Greenwood Ave., N., Seattle, WA 98133 .

\section{Wisconsin Chapter (est. 1975)}

Kathy M. Schneider, Director, Wisconsin Interlibrary Loan Service, 728 State St., Madison, WI 53706 .

\section{Food fight ends Western Civilization}

This bit of Stanfordiana was recently discovered in a vertical file in the Reference Department at Stanford University Library:

"During the fall quarter of 1946, a student orange-throwing session so unnerved the librarian in charge of the Western Civilization Library that the Department of History requested that the Main Library take it over. The Circulation Division assumed responsibility for the library before the end of the quarter.

"In December 1950 the Western Civilization Library moved from the History Department to Temporary Building $\mathrm{A}$, where it is nearing the end of the decade." Library Bulletin, Stanford University Libraries, August 12, 1985. 

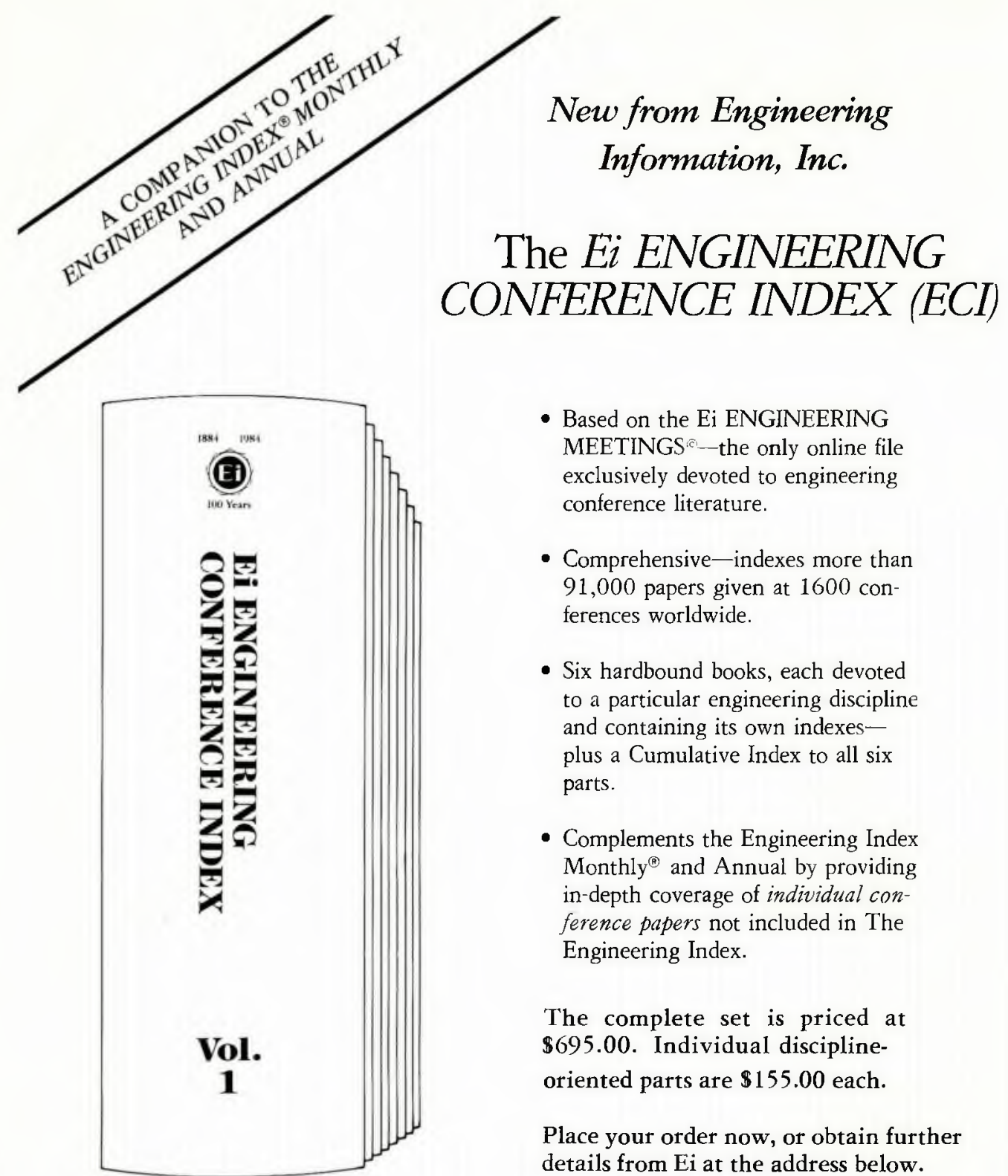

- Based on the Ei ENGINEERING MEETINGS -the only online file exclusively devoted to engineering conference literature.

- Comprehensive-indexes more than 91,000 papers given at 1600 conferences worldwide.

- Six hardbound books, each devoted to a particular engineering discipline and containing its own indexesplus a Cumulative Index to all six parts.

- Complements the Engineering Index Monthly ${ }^{\circledR}$ and Annual by providing in-depth coverage of individual conference papers not included in The Engineering Index.

The complete set is priced at $\$ 695.00$. Individual disciplineoriented parts are $\$ 155.00$ each.

Place your order now, or obtain further details from $\mathrm{E} i$ at the address below.

ENGINEERING INFORMATION, Inc. Dept C - 10

345 East 47 th Street New York, NY 10017 USA

TOLL-FREE 800-221-1044-or 212-705-7615

Telex 4990438 Cable ENGINFOR NewYork 